\title{
The ecology of mental process: a life of Gregory Bateson
}

\author{
Edmund Leach
}

Gregory Bateson: The Legacy of a Scientist. By David Lipset. Pp. 360. (Prentice-Hall: 1980.) \$16.95, US only.
Gregory Bateson, 1958

MARGaret Mead died in November 1978, Reo Fortune in November 1979, Gregory Bateson in July 1980. The conjunction of these three most unusual anthropologists in New Guinea at the end of 1932 drastically restructured their private lives. Mead, who was then married to Fortune, was later married to Bateson for 14 years. The consequences for scholarship are still difficult to assess. Fortune ceased altogether to be an effective anthropologist; Mead became an international celebrity, mainly by virtue of highly impressionistic, easy to read, accounts of field research which had already been completed when she first met Bateson. Bateson's principal contribution to anthropology, the awkwardly complex but highly original Naven (1936), was also based on fieldwork that had been completed by late 1932, and which was written up in Cambridge before his marriage to Mead. But although it is a very different sort of book from anything that either Mead or Fortune might have written, it would probably never have been written at all without their stimulus.

In 1936 the dominant style in British anthropology was the extreme empirical functionalism adopted by Malinowski and his pupils, Raymond Firth and Audrey Richards. Bateson, while declaring his respect for the work of this school, also argued that the best ethnography has the artistic merits of a great novel. In his opening pages he invoked the names of Jane Austen and Charles Doughty's Arabia Deserta.

Naven was an attempt to capture what Bateson called the ethos of Iatmul culture rather than simply to describe, in Malinowskian manner, how everything fitted together. The general attitude to ethnographic evidence which Bateson adopted, which was made to seem quite unnecessarily obscure through his mode of presentation, had much more in common with the later work of Evans-Pritchard and of Lévi-Strauss than it had with then current fashions. But although Naven was ridiculed at the time by Malinowski, along with Mead's Sex and Temperament in Three New Guinea Societies and Benedict's Patterns of Culture, it was a 弚 book that was read with great interest by Malinowski's younger pupils, as I can vouch from my experience.

Bateson usually described himself as an anthropologist, but he also had polymathic interests in such fields as animal behaviour, cybernetics and the psychology of schizophrenia. His enduring reputation, which may well prove to be very considerable, is likely to derive as much from these other interstitial activities as from his direct contributions to anthropology.

Lipset's biography, which was published a few weeks before Bateson's death, is a brilliant performance. He had the full collaboration of Bateson himself and of all members of his entourage, including access to family papers and letters, but many of the most interesting passages in the book derive from the personal recollections of those who had known Bateson and whose opinions, as expressed in unstructured interviews, were recorded by Lipset on tape. A great variety of people collaborated in this way, including both Mead and Fortune, and the author has shown astonishing skill and tact in deducing, from what must often have seemed very contradictory and prejudiced evidence, a balanced account of the life and intellectual development of a man whose persistent curiosity about matters which most of us take for granted sometimes came close to genius.

Bateson's family background was academic Cambridge in high degree. His grandfather, W. H. Bateson, was master of St John's College from 1857 to 1882 ; his father, William Bateson, was the celebrated zoologist whose renown stemmed from his pugnacious vindication of the genetics of Mendel against the statistical biometrics of Weldon and Pearson. William Bateson invented much of the technical language of modern genetics including the word "genetics" itself. Gregory was clearly greatly influenced by his father; indeed his first publication was a joint-authorship contribution to the Journal of Genetics "On certain aberrations of the red-legged partridges ..." (1926), published when Gregory was 22 .

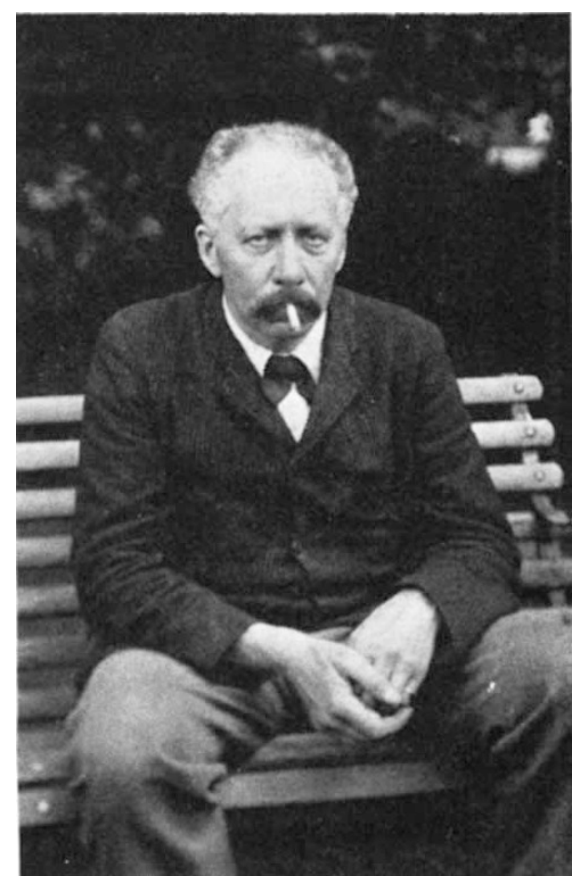

William Bateson, July 1907

But Gregory's intellectual heritage was not restricted to biology. It was William Bateson who first introduced Geoffrey Keynes to the art of William Blake, a field in which Sir Geoffrey, at the age of 93 , is 
now an acknowledged world authority. This was an enthusiasm which Gregory shared and which is somehow reflected in much of his later work. But probably the most important influences on Bateson's thinking came from his close friend $\mathrm{C}$. $\mathrm{H}$. Waddington, the Edinburgh geneticist. Gregory never adopted the Marxist view of science favoured by Waddington, but he did share many of the latter's humanist concerns. What these concerns were is summed up in the titles of Gregory's last two substantial publications, an essay collection, Steps to an Ecology of Mind (1972), and Mind and Nature: A Necessary Unity (1979), the latter written at a time when Gregory was fully aware that he was suffering from terminal cancer.

Gregory was not a vitalist; he saw very clearly that the scientific explanation of human behaviour must be of essentially the same kind as the scientific explanation of the behaviour of dolphins. But he was too good a cultural anthropologist to be taken in by the kind of reductionism that is favoured by some of the more simpleminded sociobiologists. The human mind cannot be explained away either as a genetically pre-programmed machine or as an illusory side effect of conditioned reflexes.

Gregory's interests always remained biological; but the focus of his attention was not confined to the human being as a biological organism. It was Man in his social interactions and Man as a species adapted to extremely sophisticated forms of interpersonal communication that provoked his most challenging suggestions. But they were suggestions rather than proven facts. His theories about the nature of schizophrenia and about "the double bind" influenced a wide variety of practising psychotherapists, but they were often misunderstood and they were not of a sort which lend themselves to verification.

Academically he was always a loner; he seldom occupied any position which called for formal teaching. He exercised his influence in private informal seminars and conference discussions and it is difficult to pin down just what that influence was. Gregory was a guru. I know that I myself found him one of the most exciting and inspiring "teachers" I have ever met.

Gregory himself would probably have claimed that his main claim to fame was his application of ideas borrowed from cybernetics to an understanding of the feedback which occurs in person to person interactions. But what he had to say on such matters often contained a good deal of blarney; he had a scientific attitude, but he was not an exact scientist and he was not a mathematician.

Lipset recognizes these limitations. Inspired in his youth by the art of Blake and the laws of Mendel, Gregory aspired to make comparable innovations. He did not succeed, but his contributions to our understanding of the position of mind in

\section{IMAGE UNAVAILABLE FOR COPYRIGHT REASONS}

From left: Gregory Bateson, Margaret Mead, Lois Bateson and Barkev Kasarjian

the physical world and to the complex relationships which link form and process are far from negligible.

There is much more to Lipset's book than I have been able to summarize here. The account of the intellectual atmosphere in which Gregory grew up is particularly impressive. The book as a whole makes a most timely and fitting memorial.

Edmund Leach is a Fellow of King's College, Cambridge.

\section{Beveridge on discovery}

\section{P. B. Medawar}

Seeds of Discovery. By W.I.B. Beveridge. Pp.130. (Heinemann/W.W. Norton: 1980.) Hardback £6.95, \$12.95; paperback £3.90.

THIS book is a sequel to the author's lively and readable The Art of Scientific Investigation (Heinemann, 1957). Seeds is readable too - not least because of the wealth of anecdotes and other illustrative material which help the author to make his points; it is a learned man who will learn nothing from Beveridge's pages. Amidst much that is familiar I was very interested to learn that a former Vice President of the National Academy of Sciences had published a demonstration that flight by heavier-than-air machines was not possible.

The present book is not nearly such a success, unfortunately; it is not very original and is in places lamentably trite. Nowhere was I struck, as one always hopes to be, by some felicity of thought or writing. Indeed, I found myself in the disagreeable position of having reason constantly to find fault. As to triteness, consider such a passage as this:

Scientists do not work in isolation. All are members of the world-wide scientific community. It is joined together by communication through scientific journals and meetings, which are an essential part of science. Formal and informal discussions at scientific meetings, sometimes involving conflict of views and arguments, are a feature of the scientific life.

This is the writing of someone who has nothing very original to say.

The book throughout has a slightly aggrieved and truculent air arising mainly out of the very low opinion Beveridge holds of philosophers of science, whom he accuses of trying to foist on us the notion that scientists operate something that might be called 'the scientific method' the existence of which, as he rightly says, is a myth. Of the leading philosophers of science, however, it was only Francis Bacon and John Stuart Mill who put before the public an integral body of thought - an organon - that could pass as an exposition of 'the scientific method'. Popper did not, nor did Kuhn. Among Beveridge's many causes of complaint is that philosophers of science have "failed to appreciate the cardinal role that chance and opportunism play in research, and most have dismissed the subject as hardly worthy of their serious consideration'". 